\title{
STATUS WAKAF SAHAM PADA EMITEN YANG KELUAR \\ DARI DAFTAR EFEK SYARIAH (DES)
}

oleh :

\author{
M. E. Burhanudin \\ Program Pascasarjana Hukum Ekonomi Syariah \\ Universitas Islam Negeri Sunan Gunung Djati Bandung \\ Email :mochboerhand23@gmail.com
}

\begin{abstract}
ملخص
الوقف آلة من آلات لحل مشكلة الفقر وحدها حيث يهدف الوقف لنيل العدالة الاجتماعية والاقتصادية. تحويل الأسهم الشرعية إلى الوقف بغرض تحقيق الحوائج الإنتاجية والحوائج الاجتماعية. الأسهم الشرعية هي الأسهم التي لها معايير تنظمها لائحة سلطة الخدمات المالية وتم وضعها في قائمات البورصة الشرعية. الشركة التي تدرج في قائمات البورصة الشرعية وتخرج وقف بعض أسهمها أو توزع ريع أسهمها إلى ناظر الأوقاف أو المؤسسة التي تتولى إدارة وقف الأسهم. فتساهم الشركة في التقدم الاقتصادي للأمة. ولكن وجدنا من ناحية التطبيق وقف الأسهم من الشركة الخارجة من قائمات البورصة الشرعية فتشبه وضع ذلك وقف الأسهم من ناحية شرعيتها حيث إن الواقف (الشركة) لاتكون ضمن قائمات البورصة الشرعية. ونتيجة هذا البحث، يلخص الباحث: أولا:أن يوافق عملية وقف الأسهم في مؤسسة صندوق الوقف الإندونيسي القواعد الشرعية و سجلت المؤسسة رسميا في هيئة الأوقاف الإندونيسية، ولكن توجد الشركة الواقفة الخارجة من قائمات البورصة الشرعية. ثانيا: وقفت الشركة بعض أسهمها الخارجة من قائمات البورصة الشرعية. ثالثا: وافقت عملية وقف الأسهم مع القانون رقم 41 سنة 2004 عن الوقف ، ومازال يمتاج إلى لائحة تطبيقية تفصيلية تنظم وقف الأسهم. وانطلاقا من خلاصة هذا البحث، استخرج الباحث نتائج أن سبب حدوث وقف الأسهم من الشركة الخارجة من قائمات البورصة الشرعية هو عدم لوائح خاصة تنظم وقف الأسهم، فتطبيق علمية وقف الأسهم من دون أي لوائح تخصه. اقترح الباحث إلى الحكومة وهيئة الأوقاف الإندونيسية إصدار القانون أو لائحة حكومية تنظم وقف الأسهم إجرائيا تطبيقيا تفصيليا حيث يعمل وقف الأسهم على شكل صحيح ويكون قادرا على تحقيق وتوفير فوائد للتقدم الاقتصادي للشعب. مفتاح الكلمات: لائحة سلطة الخدمات المالية، قائمات البورصة الشرعية، مؤسسة صندوق الوقف الإندونيسي، هيئة الأوقاف الإندونيسية، شركة (مصدري).
\end{abstract}

\section{Abstract}

The Waqf is one of the instruments for reducing poverty aimed at socio-economic justice. Conversion of shares into Islamic Waqf productive or social purposes. Shares of Sharia has certain criteria that are set forth in the regulation of the financial services authority (POJK), and classified in the list of Shariah-compliant effects (DES). Issuers listed in the list of Shariah-compliant effects (DES) and issued a stock dividend or endowments to nadzir or institutions manage endowments. As a contribution to the economic progress of the people. But in practice many endowments received shares of issuers that have come out from the list of effects of Sharia (DES), so many stocks that endowments still unclear status because waqif (issuers) has no entry criterion of the stock. The results of such research, researchers concluded: first, implementation of the endowments Indonesian waqf savings (TWI) is in compliance with Islamic 
criteria and has also been listed in Indonesian Waqf Board (BWI). However, there is still the presence of companies (issuers) that is not in accordance with Islamic criteria that has been mewakafkan shares; Second, there are issuers that have been mewakafkan shares, but has not been in accordance with the criteria of the list of Shariah-compliant effects (DES); third, implementation of the Waqf's shares were in accordance with Act No. 41 of the year 2004, but has not yet been regulated specifically related to the endowments of the stock. Based on these conclusions, the researchers obtained the findings that the existence of the Waqf shares of issuers that are not in accordance with Islamic criteria due to the presence of special provisions which have not yet set up endowments stock, so in practice the rules walk without spesifk. Researchers suggest should the Government and the Indonesian Waqf Board soon to make laws and regulations concerning Waqf stock and operational standards procedure so that the Waqf stock goes properly and able to provide benefits for the economic advancement of the people.

Keywords: financial services authority rules, the list of Shariah-compliant effects, Indonesian waqf savings, Indonesian waqf board, issuers

\section{Abstrak}

Wakaf merupakan salah satu instrumen untuk mengurangi kemiskinan yang bertujuan untuk keadilan sosial ekonomi. Konversi saham syariah menjadi wakaf untuk keperluan produktif atau sosial. Saham syariah memiliki kriteria tertentu yang diatur dalam peraturan otoritas jasa keuangan (POJK), dan diklasifikasikan dalam daftar efek syariah (DES). Emiten yang tercantum dalam daftar efek syariah (DES) dan mengeluarkan wakaf saham atau pun dividen kepada nadzir atau lembaga yang mengelola wakaf. Sebagai bentuk kontribusi untuk kemajuan ekonomi umat. Namun dalam pelaksanaannya banyak wakaf saham yang diterima dari emiten yang sudah keluar dari daftar efek syariah (DES), sehingga banyak wakaf saham yang masih belum jelas statusnya karena waqif (emiten) sudah tidak masuk kriteria saham syariah. Hasil dari penelitian tersebut, peneliti menyimpulkan: pertama, pelaksanaan wakaf saham di Tabung Wakaf Indonesia (TWI) sudah sesuai dengan kriteria syariah dan juga telah terdaftar di Badan Wakaf Indonesi (BWI). Akan tetapi, masih adanya perusahaan (emiten) yang tidak sesuai dengan kriteria syariah yang telah mewakafkan sahamnya; kedua, terdapat emiten yang telah mewakafkan sahamnya, namun belum sesuai dengan kriteria daftar efek syariah (DES); ketiga, pelaksanaan wakaf saham telah sesuai dengan UU No. 41 tahun 2004, namun belum diatur secara spesifik terkait dengan wakaf saham. Berdasarkan kesimpulan tersebut, peneliti memperoleh temuan bahwa adanya wakaf saham dari emiten yang tidak sesuai dengan kriteria syariah disebabkan karena belum adanya ketentuan khusus yang mengatur wakaf saham, sehingga dalam pelaksanaannya berjalan tanpa aturan yang spesifk. Peneliti menyarankan hendaknya pemerintah dan Badan Wakaf Indonesia segera membuat Undang-undang dan peraturan tentang wakaf saham dan standar operasional prosedurnya agar wakaf saham berjalan semestinya dan mampu memberikan manfaat bagi kemajuan ekonomi umat.

Kata Kunci : peraturan otoritas jasa keuangan, daftar efek syariah, tabung wakaf indonesia, badan wakaf indonesia, emiten

\section{A. Pendahuluan}

\section{Latar belakang masalah}

Pada perkembangannya wakaf tidak hanya berbentuk barang tetap saja seperti tanah dan bangunan, tetapi juga barang bergerak seperti uang dan surat berharga. Wakaf uang (cash wakaf/waqf al-Nuqud) telah lama dipraktikkan di berbagai negara seperti Malaysia, Bangladesh,
Mesir, Kuwait dan negara-negara Islam di Timur Tengah lainnya.

Dalam sejarah, wakaf uang telah dipraktikkan sejak awal abad kedua Hijriyah. Hal tersebut dilakukan berdasarkan pendapat beberapa ulama. Di antaranya adalah pendapat Imam Al-Zuhri yang telah memfatwakan bahwa mewakafkan dinar hukumnya boleh, dengan cara mewakafkan dinar tersebut sebagai modal usaha kemudian 
keuntungannya disalurkan pada mauquf 'alaih. (Abdul Ghofur Anshori:2006)

Pada wakaf tanah, yang dapat menikmati harta wakaf tanah dan bangunan adalah rakyat yang berdomisili di sekitar harta wakaf tersebut berada. Sementara rakyat miskin sudah sangat menyebar luas di seluruh Indonesia sehingga dibutuhkan sumber pendanaan baru yang tidak terikat tempat dan waktu. Seiring dengan kebutuhan dana untuk pengentasan kemiskinan yang sangat besar dan lokasinya tersebar di luar daerah para wakif tersebut, timbulah pemikiran baru untuk berwakaf dengan uang. (Adrian Sutedi:2011)

Secara umum, penerapan prinsip syariah dalam industri pasar modal khususnya pada instrumen saham dilakukan berdasarkan penilaian atas saham yang diterbitkan oleh masingmasing perusahaan, karena instrument saham. Saham adalah sertifikat yang menunjukkan bukti kepemilikan suatu perusahaan, dan pemegang saham memiliki hak klaim atas penghasilan dan aktiva perusahaan. Harga suatu saham akan cenderung naik apabila suatu saham mengalami kelebihan penawaran(Khaerul Umam:2013)

Dewan Syariah Nasional (DSN) mendefinisikan Saham Syariah adalah bukti kepemilikan atas suatu perusahaan yang memenuhi kriteria dan tidak bertentangan dengan syariat islam, dan tidak termasuk saham yang memiliki hak-hak istimewa. (Syari \& Nasional, 2008)

Menurut Direktur Bursa Efek Indonesia, wakaf saham adalah salah satu jenis dari wakaf produktif.Konversi saham syariah menjadi wakaf untuk keperluan produktif atau sosial. Investor syariah terlibat aktif menjadi pelaku wakaf. (http://www.ekonomisyariah.org/5620/ mengenal-wakaf-saham/)

Wakaf merupakan salah satu instrumen untuk mengurangi kemiskinan yang bertujuan untuk keadilan sosial ekonomi. Wakaf di Indonesia memiliki potensi yang sangat besar, dimana wakaf di Indonesia mencapai Rp 3 triliun per tahun, sedangkan wakaf yang terkumpul berupa tanah sebanyak 45.385,78 Ha yang tersebar di seluruh Indonesia (http://siwak.kemenag.go.id/).

Wakaf melalui instrument saham yang dilaksanakan oleh emiten ini diawasi langsung oleh otoritas jasa keuangan (OJK), sesuai dengan aturan yang berlaku. Saham syariah memiliki criteria tertentu yang diatur dalam peraturan otoritas jasa keuangan (POJK), dan diklasifikasikan dalam daftar efek syariah (DES). Otoritas Jasa Keuangan (OJK) menerbitkan Daftar Efek Syariah (DES) Periode II 2016. Dari 345 saham syariah yang masuk dalam DES pada periode ini ada 31 saham emiten yang baru masuk dalam DES dan 11 saham emiten yang keluar dari DES Periode II setelah sebelumnya sempat masuk di periode I. (http://akucintakeuangansyariah.com)

Saham-saham yang sudah tidak terdaftar ataupun dikeluarkan dari Daftar Efek Syariah (DES) namun telah mewakafkan sahamnya di Tabung Wakaf Indonesia yaitu: (http:// tabungwakaf.com/wakaf-saham-di-twi-bisa/)

1. PT. Capitalinc Finansial

2. PT. Panin Life Finansial

3. PT Bentoel International

4. Jakarta Internasional Hotel

5. BII Tbk

6. Sahid Jaya Hotel

7. Bank Arthagraha International.

Perusahaan (emiten) yang tercantum dalam daftar efek syariah (DES) dan mengeluarkan wakaf saham atau pun dividen kepada nadzir atau lembaga yang mengelola wakaf. Sebagai bentuk kontribusi untuk kemajuan ekonomi umat. Namun dalam pelaksanaannya banyak wakaf saham yang diterima dari emiten yang sudah keluar dari daftar efek syariah (DES), sehingga banyak wakaf saham yang masih belum jelas statusnya karena waqif (emiten) sudah tidak masuk kriteria saham syariah.

Berdasarkan latar belakang tersebut, penulis merasa tertarik untuk melakukan penelitian lebih lanjut mengenai masalah tersebut. Maka dari itu, penulis akan menuangkannya dalam sebuah 
penelitian yang berjudul "Status Wakaf Saham Pada Emiten Yang Keluar Dari Daftar Efek Syariah (DES)"

\section{Rumusan masalah dan pertanyaan penelitian}

Berdasarkan latar belakang di atas dapat diambil rumusan masalah bahwa wakaf merupakan salah satu instrumen untuk lebih mensejahterakan umat. Dalam pelaksanaan wakaf saham, beberapa emiten yang tercantum dalam daftar efek syariah (DES) mengeluarkan wakaf dari saham atau dividen. Namun ada wakaf yang diterima dari emiten yang sudah tidak terdaftar dalam daftar efek syariah (DES). Dari rumusan masalah di atas dapat dibuat beberapa pertanyaan sebagai berikut:

1) Bagaimana mekanisme investasi wakaf melalui instrumen saham?

2) Bagaimana karakteristik emiten yang sesuai dengan daftar efek syariah (DES)?

3) Bagaimana analisis hukum ekonomi syariah terhadap wakaf saham bagi emiten yang keluar dari daftar efek syariah (DES)?

\section{Tujuan dan kegunaan penelitian}

Berdasarkan pada pokok masalah diatas, tujuan yang ingin penyusun capai dalam penelitian ini adalah sebagai berikut:

1) Untuk mengetahui mekanisme investasi wakaf melalui instrumen Saham Syariah.

2) Untuk mengetahui karakteristik emiten yang sesuai dengan daftar efek syariah (DES).

3) Untuk Bagaimana analisis hukum ekonomi syariah terhadap wakaf saham bagi emiten yang keluar dari daftar efek syariah (DES)

Adapun kegunaan penelitian, sebagai berikut:

1) Kegunaan Secara Teoritis

a) Memberikan sumbangan pemikiran dalam perkembangan ilmu hukum Islam, khususnya dalam bidang wakaf produktif melalui instrumen pasar modal syariah yaitu Saham Syariah serta dapat menambah kepustakaan. b) Menambah khasanah keilmuan di bidang fikih, terutama yang berkaitan dengan pelaksanaan wakaf saham yang sesuai dengan syariah, baik yang bersifat teoritik maupun praktis.

c) Untuk memberikan kontribusi terhadap pengembangan ekonomi Islam bagi akademisi dan bagi praktisi sebagai pertimbangan dalam pelaksanaan wakaf saham syariah di Indonesia.

2) Kegunaan Secara Praktis

a) Mencari kesesuaian antara teori yang telah didapatkan di bangku kuliah dengan kenyataan di lapangan.

b) Memberikan pengetahuan tentang mekanisme dalam hal berwakaf saham.

c) Diharapkan hasil penelitian ini dapat bermanfaat bagi semua pihak yang berkaitan dengan penelitian ini yaitu bagaimana pelaksanaan wakaf saham yang sesuai dengan kaidah Islam.

\section{B. Metodologi}

Metode penelitian adalah cara melakukan sesuatu dengan menggunakan pikiran secara seksama untuk mencapai suatu tujuan dengan cara mencari, mencatat, merumuskan, dan menganalisis sampai menyusun laporan. (Cholid Narbuko dan Abu Achmadi, Metodologi Penelitian, 2003) Istilah metodelogi berasal dari kata metode yang berarti jalan, namun demikian, menurut kebiasaan metode dirumuskan dengan kemungkinan-kemungkinan suatu tipe yang dipergunakan dalam penelitian dan penilaian. Riset atau penelitian merupakan aktifitas ilmiah yang sistematis, berarah dan bertujuan. Maka, data atau informasi yang dikumpulkan dalam penelitian harus relevan dengan persoalan yang dihadapi. Artinya, data tersebut berkaitan, mengenal dan tepat. (Soerjono Soekanto, Pengantar Penelitian Hukum, 2012) Jadi penelitian 
itu hal yang sangat unik yang dilakukan oleh peneliti dalam melakukan penelitian.

Dalam penelitian ini menggunakan jenis penelitian empiris. Sebab dari judul yang diangkat mengacu kepada status hukum wakaf saham pada emiten yang keluar dari daftar efek syariah (DES) yang mengacu kepada UU No. 41 tahun 2004 tentang wakaf dan kompilasi hukum ekonomi syariah (KHES).

Metode penelitian merupakan suatu cara yang digunakan dalam mengumpulkan data penelitian dan membandingkan dengan standar ukuran yang telah ditentukan. Dalam hal ini peneliti menggunakan beberapa perangkat penelitian yang sesuai dalam metode penelitian ini guna memperoleh hasil yang maksimal, antara lain sebagai berikut :

\section{Jenis Penelitian}

Jenis penelitian dalam penelitian ini adalah yuridis empiris yang dengan kata lain adalah jenis penelitian hukum sosiologis dan dapat disebut pula dengan penelitian lapangan, yaitu mengkaji ketentuan hukum yang berlaku serta apa yang terjadi dalam kenyataannya di masyarakat. (Bambang Waluyo, Penelitian Hukum Dalam Praktek, 2002) Atau dengan kata lain yaitu suatu penelitian yang dilakukan terhadap keadaan sebenarnya atau keadaan nyata yang terjadi di masyarakat dengan maksud untuk mengetahui dan menemukan fakta-fakta dan data yang dibutuhkan, setelah data yang dibutuhkan terkumpul kemudian menuju kepada identifikasi masalah yang pada akhirnya menuju pada penyelesaian masalah.

Penelitian ini termasuk kedalam penelitian Empiris, karena hendak mengetahui status hukum wakaf saham pada emiten yang keluar dari daftar efek syariah (DES) yang mengacu kepada UU No. 41 tahun 2004 tentang wakaf dan kompilasi hukum ekonomi syariah (KHES). .

\section{Pendekatan Penelitian}

Metode pendekatan yang digunakan dalam penelitian ini adalah pendekatan yuridis sosiologis. Pendekatan yuridis sosiologis adalah Mengidentifikasi dan mengkonsepsikan hukum sebagai institusi sosial yang riil dan fungsional dalam sistem kehidupan yang nyata". (Soerjono Soekanto, Pengantar Penelitian Hukum, 2012). Pendekatan yuridis sosiologis adalah menekankan penelitian yang bertujuan memperoleh pengetahuan hukum secara empiris dengan jalan terjun langsung ke obyeknya yaitu mengetahui status hukum wakaf saham pada emiten yang keluar dari daftar efek syariah (DES).

Pendekatan perundang-undangan (statute approach) dilakukan dengan menelaah semua regulasi atau peraturan perundang-undangan yang bersangkut paut dengan isu hukum yang akan diteliti, yaitu penelitian terhadap norma-norma yang terdapat dalam Undangundang No. 41 tahun 2004 tentang wakaf dan kompilasi hukum ekonomi syariah (KHES).

3. Lokasi Penelitian

Lokasi penelitian ini bertempat Di Kantor Tabung Wakaf Indonesia (TWI) yang berlokasi Jl. Ir.H. Juanda, No. 50, Ciputat, Perkantoran Ciputat Indah Permai Blok C25, Cempaka Putih, Ciputat Timur, Kota Tangerang Selatan, Provinsi Banten. Serta mengamati langsung untuk menggali tentang regulasi wakaf tunai di kantor Badan Wakaf Indonesia yang berlokasi di Sekeratariat Gedung Bayt Al Quran Taman Mini Indonesia Indah (TMII) Jl. Raya TMII Pintu 1 - Jakarta Timur 13560.

4. Jenis dan Sumber data

Sumber data yang digunakan di dalam penelitian ini diambil dari data primer dan data sekunder.

a. Data primer adalah data yang diperoleh secara langsung dari sumber pertama yang terkait dengan permasalahan yang akan dibahas. (Amiruddin, Pengantar Metode Penelitian Hukum. 2006) Sumber data 
diperoleh dari lapangan secara langsung dengan wawancara kepada:

1) Ketua Tabung Wakaf Indonesia (TWI)

2) Kepala Bagian Research and Development Badan Wakaf Indonesia (BWI)

b. Data sekunder adalah data-data yang diperoleh dari buku-buku sebagai data pelengkap sumber data primer. Sumber data sekunder penelitian ini adalah datadata yang diperoleh dengan melakukan kajian pustaka seperti buku-buku ilmiah, hasil penelitian dan sebagainya. (Marzuki, Metodologi Riset, 1983) Data sekunder mencakup dokumen-dokumen, buku, hasil penelitian yang berwujud laporan, dan seterusnya. Adapun buku/laporan yang menjadi sumber data sekunder adalah buku/laporan tentang wakaf tunai dan hukum ekonomi syariah tentang wakaf.

\section{Metode Pengumpulan Data}

Pada bagian ini peneliti mendapatkan data yang akurat dan otentik karena dilakukan dengan mengumpulkan sumber data baik data primer dan sekunder, yang disesuaikan dengan pendekatan penelitian. Teknik pengumpulan data primer dan data sekunder yang digunakan adalah :

a. Wawancara Langsung

Wawancara adalah situasi peran antara pribadi bertatap muka, ketika seseorang yakni pewawancara mengajukan pertanyaan-pertanyaan yang dirancang untuk memperoleh jawaban yang relevan dengan masalah penelitian kepada responden.

Wawancara langsung dalam pengumpulan fakta sosial sebagai bahan kajian ilmu hukum empiris, dilakukan dengan cara tanya jawab secara langsung dimana semua pertanyaan disusun secara sistematis, jelas dan terarah sesuai dengan isu hukum, yang diangkat dalam penelitian. Wawancara langsung ini dimaksudkan untuk memperoleh informasi yang benar dan akurat dari sumber yang ditetapkan sebelumnya. Wawancara tersebut semua keterangan yang diperoleh mengenai apa yang diinginkan dicatat atau direkam dengan baik. Wawancara dilakukan untuk memperoleh keterangan secara lisan guna mencapai tujuan yaitu mendapatkan informasi yang akurat dari narasumber yang berkompeten.

b. Studi Dokumentasi

Teknik dokumentasi adalah teknik pengumpulan data yang berwujud sumber data tertulis atau gambar. Sumber tertulis atau gambar berbentuk dokumen resmi, buku, majalah, arsip, dokumen pribadi, dan foto yang terkait dengan permasalahan penelitian. (Sudarto, Metodologi Penelitian Filsafat, 2002) Dilakukan untuk memperoleh dan memahami konsep dan teori serta ketentuan tentang status hukum wakaf saham pada emiten yang keluar dari daftar efek syariah (DES) yang mengacu kepada UU No. 41 tahun 2004 tentang wakaf dan kompilasi hukum ekonomi syariah (KHES).

6. Metode Pengolahan Data

Pengolahan data harus sesuai dengan keabsahan data. (Andi Prastowo, 2012) Cara kualitatif artinya menguraikan data dalam bentuk kalimat yang teratur, runtun, logis, tidak tumpang tindih dan efektif sehingga memudahkan pemahaman dan interpretasi data. Adapun tahapan-tahapan dalam menganalisis data yaitu:

a. Editing/edit

Editing adalah kegiatan yang dilakukan setelah menghimpun data di lapangan. Proses ini menjadi penting karena kenyataannya bahwa data yang 
terhimpun kadangkala belum memenuhi harapan peneliti, ada di antaranya yang kurang bahkan terlewatkan. (Suharsimi Arikunto, Prosedur Penelitian, 2002) Oleh karena itu, untuk kelengkapan penelitian ini, maka proses editing ini sangat diperlukan dalam mengurangi data yang tidak sesuai dengan tema penelitian ini, yaitu status hukum wakaf saham pada emiten yang keluar dari daftar efek syariah (DES) yang mengacu kepada UU No. 41 tahun 2004 tentang wakaf dan kompilasi hukum ekonomi syariah (KHES).

b. Calssifying

Agar penelitian ini lebih sistematis, maka data hasil wawancara diklasifikasikan berdasarkan kategori tertentu, yaitu berdasarkan pertanyaan dalam rumusan masalah, sehingga data yang diperoleh benar-benar memuat informasi yang dibutuhkan dalam penelitian ini.

c. Verifikasi

Verifikasi data adalah mengecek kembali dari data-data yang sudah terkumpul untuk mengetahui keabsahan datanya apakah benar-benar sudah valid dan sesuai dengan yang diharapkan peneliti. (Lexy J. Moloeng, Metode Penelitian Kualitatif, 2002) Jadi tahap verifikasi ini merupakan tahap pembuktian kebenaran data untuk menjamin validitas data yang telah terkumpul. Verifikasi ini dilakukan dengan cara mendengarkan dan mencocokkan kembali hasil wawancara yang telah dilakukan sebelumnya dalam bentuk rekaman dengan tulisan dari hasil wawancara peneliti ketika wawancara, kemudian menemui sumber data subyek dan memberikan hasil wawancara dengannya untuk ditanggapi apakah data tersebut sesuai dengan yang informasikan olehnya atau tidak. Disamping itu, untuk sebagian data peneliti memverifikasinya dengan cara trianggulasi, yaitu mencocokkan (crosscheck) antara hasil wawancara dengan subyek yang satu dengan pendapat subyek lainnya, sehingga dapat disimpulkan secara proporsional.

d. Analisis data

Analisis data adalah proses mengorganisasikan dan mengurutkan data kedalam pola, kategori dan satuan uraian dasar sehingga dapat ditemukan tema dan dapat dirumuskan hipotesis kerja.

Jadi dalam analisis data bertujuan untuk mengorganisasikan data-data yang telah diperoleh. Setelah data dari lapangan tekumpul dengan metode pengumpulan data yang telah dijelaskan diatas, maka penulis akan mengelola dan menganalisis data tersebut dengan menggunakan analisisis deskriptif kualitatif.

Analisis data kualitatif adalah upaya yang dilakukan dengan jalan bekerja dengan data, mengorganisasikan data, dan memilah-milahnya menjadi satuan yang dapat dikelola, mensistensikannya, mencari dan menemukan pola, menemukan apa yang penting dan apa yang dipelajari, dan menemukan apa yang dapat diceritakan kepada orang lain. (Lexy J. Moleong, Metodelogi Penelitian Kualitatif, 2010) Analisis data kualitatif adalah suatu teknik yang menggambarkan dan menginterpretasikan data-data yang telah terkumpul, sehingga diperoleh gambaran secara umum dan menyeluruh tentang keadaan sebenarnya.

e. Kesimpulan

Kesimpulan merupakan hasil suatu proses penelitian. Setelah langkah- langkah di atas, maka langkah yang terakhir adalah menyimpulkan dari analisis data untuk menyempurnakan penelitian ini, Sehingga mendapatkan keluasan ilmu khususnya bagi peneliti serta bagi para pembacanya. Pada tahap ini peneliti 
membuat kesimpulan dari keseluruhan data-data yang telah diperoleh dari kegiatan penelitian yang sudah dianalisis kemudian menuliskan kesimpulannya.

\section{Kerangka Teoritik}

Ekonomi syariah merupakan ilmu pengetahuan sosial yang mempelajari masalahmasalah ekonomi masyarakat, yang di ilhami oleh nilai-nilai Islam. (Khaerul Umam : 2013) Dalam menjalankan aktivitas ekonomi, Islam membawa misi sosial karena yang menjadi dimensi keberhasilan dalam ekonomi syariah bukan hanya di dunia akan tetapi di akhirat juga.

Harta (al-maal) merupakan komponen pokok dalam kehidupan manusia, unsur dlaruri yang tidak bisa ditinggalkan begitu saja. Dengan harta, manusia bisa memenuhi kebutuhannya, baik yang bersifat materi ataupun immateri. Dalam kerangka memenuhi kebutuhan tersebut, terjadilah hubungan horizontal antar manusia (mu'amalah), karena pada dasarnya tidak ada manusia yang sempurna dan dapat memenuhi kebutuhanna sendiri, akan tetapi saling membutuhkan terkait dengan manusia lainnya.

Dalam konteks tersebut, harta hadir sebagai obyek transaksi harta bisa dijadikan sebagai obyek dalam transaksi jual beli, sewa-menyewa, partnership (kontrak kerjasama), atau transaksi ekonomi lainnya. Selain itu, dilihat dari karakteristik dasarnya (nature), harta juga bisa dijadikan sebagai obyek kepemilikan, kecuali terdapat faktor yang menghalanginya.

\section{Definisi Harta}

Secara linguistik, al maal didefinisikan sebagai segala sesuatu yang dapat mendatangkan ketenangan, dan bisa dimiliki oleh manusia dengan sebuah upaya (fi'il), baik sesuatu itu berupa dzat (materi) seperti; komputer, lamera digital, hewan ternak, tumbuhan, dan lainnya. Atau pun berupa manfaat, seperti, kendaraan, atau tempat tinggal.(Wahbah AzZuhaili:2007)
Dilihat dari kacamata istilah fiqh, ulama berneda pendapat tentang definisi al-maal, perbedaan itu muncul dari makna atau substansi yang dihadirkan dalam definisi. Perbedaan pandangan tersbut dapat dikatagorikan dalam dua pendapat.

a. Pendapat Hanafiyah

Menurut Hanafiyah, al-maal adalah segala sesuatu yang mungkin dimiliki, disimpan, dan dimanfaatkan. Pendapat ini mensyaratkan dua unsur yang harus terdapat dalam al-maal;

b. Pendapat Mayoritas Ulama

Mayoritas ulama fiqh, al-maal adalah segala sesuatu yang memiliki nilai, dimana bagi orang yang merusaknya, berkewajiban untuk menanggung atau menggantinya. Lebih lanjut Imam Syafii mengatakan, al-maal dikhususkan pada sesuatu yang bernilai dan bisa diperjualbelikan dan memiliki konsekuensi bagi yang merusaknya. Berdasarkan pengertian ini, al-maal haruslah sesuatu yangdapat merefleksikan sebuah nilai finansial, dalam arti ia bisa diukur dengan satuan moneter.

2. Hak dan Manfaat

Manfaat dan hak yang terkait dengan harta, atau pun hak yang tidak terkait dengan harta, menurut pandangan hanafiyah tidak termasuk dalam katagori harta. Karena tidak dimungkinkan untuk meiliki dan\ menyimpan dzatnya ('ain). Selain itu, manfaat dan hak bersifat maknawi (ingtangible), tidak permanen dan akan berkurang secara bertahap.

Menurut jumhur ulama, hak dan manfaat tetap merupakan harta, karena bisa dimungkinkanuntuk memiliki dan menjaganya, yaitu dengan menjaga asaldan sumbernya. Dengan alasan, karena ada hak dan manfaatlah seseorang bermaksud untuk memiliki suatu benda (dzat, materi). Dan karenanya, orang suka dan berlomba untuk mendapatkannya. Jika sudah tidak terdapat 
manfaat dan hak pada suatu benda, maka tidak mungkin orang akan mengejar untuk memiliki suatu benda.

Berdasarkan penjelasan ini, dapat dipahami bahwa substansi seseorang memilii banda (dzat, materi) adalah karena adanya unsur manfaat, jika manfaat itu telah tiada, maka ia akan cenderung untuk meninggalkannya. (Wahbah Az-Zuhaili:2007)

\section{Pembagian Harta}

a. Mutaqawwim dan Ghair Mutaqawwim

Menurut Wahbah Zuhaili, al-maal al mutaqawwim adalah harta yang dicapai atau diperoleh manusia dengan sebuah upaya, dan diperbolehkan oleh syara' untuk memanfaatkannya, seperti makana, pakaian, kebun apel, dan lainnya. al-maal gairu al mutaqawwim adalah harta yang belum diraih atau dicapai dengan suatu usaha, maksudnya harta tersebut belum sepenuhnya berada dalam genggaman kepemilikan manusia, seperti mutiara di dasar laut, minyak di perut bumi, dan lainnya. (Wahbah Az-Zuhaili:2007)

b. 'Iqar dan Manqul

Menurut Hanafiyah, manqul adalah harta yang memungkinkan untuk dipindah, ditransfer dari suatu tempat ke tempat lainnya, baik bentu fisiknya (dzat atau 'ain) berubah atau tidak, dengan adanya perpindahan tersebut. Diantaranya adalah uang, harta perdagangan, hewan, atau apa pun komoditas lain yang dapat ditimbang atau diukur. Sedangkan 'iqar adalah sebaliknya, harta yang tidak bisa dipindah dari satu tempat ke tempat lainnya, seperti tanah dan bangunan. Namun demikian, tanaman, bangunan atau apapun yang terdapat di atas tanah, tidak bisa dikatakan sebagai iqar kecuali ia tetap mengikuti atau bersatu dengan tanahnya. (Wahbah Az-Zuhaili:2007) c. Mitsli dan Qilmi

Al maal al mitsli adalah harta yang terdapat padanannya dipasaran, tanpa adaya perbedaan atas bentuk fisik atau bagian-bagiannya, atau kesatuannya. Harta mitsli dapat dikatagorikan menjadi empat bagian:

1) Al makilaat (sesuatu yang dapat ditakar) seperti; gandu, terigu, beras;

2) Al mauzunaat (sesuatu yang dapat ditimbang) seperti; kapas, besi, tembaga;

3) Al 'adadiyat (sesuatu yang dapat dihitung) seperti; pisang, telor, apel, begitu juga dengan hasil-hasil industri, seperti; mobil yang satu tipe, buku-buku baru, perabotan rumah, dan lainnya;

4) Aldzira'iyat (sesuatu yang dapat diukur dan memiliki persamaan atas bagianbagiannya) seperti; kain, kertas, tapi jika terdapat perbedaan atas juz-nya (bagian), maka dikatagorikan sebagai harta qimi, seperti tanah.

Al maal al qimi adalah harta yang tidak ter-dapat padanannya di pasaran, atau terdapat padanannya, akan tetapi nilai tiap satuannya berbeda, seperti domba, tanah, kayu, dan lainnya. Walaupun sama jika dilihat dari fisiknya, akan tetapi stiap satu domba memiliki nilai yang berbeda antara satu dan lainnya. Juga termasuk dalam harta qimiadalah durian, semangka yang memilki kualitas dan bntuk fisik yang berbeda.

d. Istikhlaki dan Isti'mali

Al maal al istikhlaki adalah harta yang tidak mungkin bisa dimanfaatkan kecuali dengan merusak bentuk fisik harta tersebut, seperti aneka warna makanan dan minuman, kayu bakar, BBM, uang, dan lainnya. Jika kita ingin memanfaatkan makanan dan minuman, maka kita harus 
memakan dan meminumnya sampai bentuk fisiknya tidak kita jumpai, artinya barang tersebut tidak akan mendatangkan manfaat, kecuali dengan merusaknya. (Wahbah Az-Zuhaili:2007)

Dalam pergaulan masyarakat terdapat aneka macam hubungan antara anggota masyarakat, yakni hubungan yang ditimbulkan oleh kepentingankepentingan anggota masyarakat itu. Untuk menjamin kelangsungan keseimbangan dalam perhubungan antara anggota masyarakat, diperlukan aturan-aturan hukum yang diadakan atas kehendak dan keinsyafan tiap-tiap anggota masyarakat itu.

Berkenaan dengan tujuan hukum, berikut ini adalah teori-teri tujuan hukum yang dikenal antara lain:

1. Teori etis (etische theorie)

Teori ini mengajarkan bahwa hukum bertujuan semata-mata untuk mencapai keadilan. Menurut teori ini, isi hukum semata-mata harus ditentukan oleh kesadaran etis kita mengenai apa yang adil dan apa yang tidak adil. Teori ini pertama kali dikemukakan oleh Aristoteles filsuf Yunani dalam bukunya Ethica Nicomachea dan Rhetorica yang menyatakan "hukum mempunyai tugas yang suci yaitu memberi kepada setiap orang yang berhak menerimanya”. (Drs., C.S.T. Kansil., SH:2008)

2. Teori utilitas (utiliteis theorie)

Menurut teori ini, tujuan hukum ialah menjamin adanya kemamfaatan atau kebahagiaan sebanyakbanyaknya pada orang sebanyakbanyaknya. Pencetus teori ini adalah Jeremy Betham. Dalam bukunya yang berjudul "introduction to the morals and legislation" berpendapat bahwa hukum bertujuan untuk mewujudkan semata-mata apa yang berfaedah/mamfaat bagi orang. (Drs., C.S.T. Kansil., SH:2008)

3. Teori campuran

Teori ini dikemukakan oleh Muckhtar Kusmaatmadja bahwa tujuan pokok dan pertama dari hukum adalah ketertiban. Di samping itu tujuan lain dari hukum adalah tercapainya keadilan yang berbeda-beda isi dan ukurannya menurut masyarakat dan zamannya.

4. Teori normatif-dogmatif

Tujuan hukum adalah sematamata untuk menciptakan kepastian hukum (John Austin dan van Kan). Arti kepastian hukum disini adalah adanya melegalkan kepastian hak dan kewajiban. Van Kan berpendapat tujuan hukum adalah menjaga setiap kepentingan manusia agar tidak diganggu dan terjaminnya kepastiannya.

5. Teori Peace (damai sejahtera)

Menurut teori ini dalam keadaan damai sejahtera (peace) terdapat kelimpahan, yang kuat tidak menindas yang lemah, yang berhak benar-benar mendapatkan haknya dan adanya perlindungan bagi rakyat. Hukum harus dapat menciptakan damai dan sejahtera bukan sekedar ketertiban.

\section{Pembahasan}

\section{Kondisi Objektif Tabung Wakaf Indonesia Kantor Pusat}

Tabung Wakaf Indonesia (TWI) adalah lembaga sosial yang bertujuan meningkatkan kesejahteran masyarakat dengan menggalang dan mengelola sumber daya wakaf secara produktif, profesional dan amanah. (http://tabungwakaf. com/ profil-tabung-wakaf-indonesia/) 
Pada bulan Juli 1993 telah berdiri sebuah lembaga sosial kemanusiaan yang bernama Dompet Dhuafa Republika (DDR). Sebuah lembaga yang didirikan sebagai jawaban atas keprihatinan beberapa kepemimpinan harian republika atas kondisi umat Islam yang jauh dari kondisi ideal. Awal dari perjalanannya merupakan perjuangan yang sangat berat dan sangat melelahkan, dan sekarang perjuangan yang dirintisdari awal dengan banyak pengorbanan itu lebih membuahkan hasil yang cukup menggembirakan, salah satunya diresmikannya Dompet Dhuafa Republika (DDR) sebagai Lembaga Amil Zakat Nasional (LAZNAS) yang pertama pada tahun 2001.

Berdasarkan kondisi diatas dan melihat potensi wakaf yang sangat besar maka pada tanggal 14 Juli 2005, Dompet dhuafa meluncurkan unit baru bernama Tabung wakaf Indonesia (TWI), sebagai jawaban dan solusi atas permasalahan wakaf. (Fitra Mizan:2007)

\section{Mekanisme Investasi wakaf Melalui Instrumen saham}

Dibawah ini beberapa mekanisme praktik wakaf yang terkait dengan saham sebagai berikut :

a. Wakaf uang yang diinvestasikan melalui saham

Wakaf uang ini dapat dilakukan dengan menginvestasikan dananya melalui pembelian saham-saham perusahaan baik melalui pasar modal maupun tidak. Pada praktik wakaf ini, yang menjadi objek wakaf adalah uang, hanya bentuk investasinya dikelola melalui saham. Jika wakaf uang dilakukan dengan menginvestasikan dananya melalui jual beli saham di pasar modal, maka mengikuti mekanisme transaksi saham dengan menggunakan prinsip-prinsip syariah, termasuk dalam memilih saham-saham yang tidak bertentangan dengan prinsip-prinsip syariah. Keuntungan dari jual beli saham ini yang akan disalurkan untuk mauquf 'alaih sesuai dengan ikrar wakaf. b. Wakaf saham melalui uang

Pada mekanisme ini wakaf dapat mewakilkan pada pihak nazhir atau pihak lainnya dengan menitipkan sejumlah uang yang kemudian dibelikan atau ditukar dengan saham, kemudian saham tersebut diwakafkan. Hal ini antara lain dilakukan dengan calon wakif yang ingin berwakaf saham namun belum memiliki saham. Untuk itu wakif menyerahkan sejumlah uang untuk memilih jenis saham atau menunjuk pihak nazhir memilih saham yang tepat untuk dijadikan wakaf.

Pada pola ini, saham sebagai surat berharga keuangan yang dierbitkan oleh suatu perusahaan saham paungan melakukan penjualan saham untuk meningkatkan modal perseroan. Kemudian para pembeli saham membayarkan uang pada perusahaan dan menerima sebuah sertifikat wakaf saham sebagai tanda bukti sebagai wakif dan dicatat dalam daftar saham perusahaan. Hasil-hasil pengelolaan saham yang diwakafkan tersebut oleh wakif disalurkan kepada mauquf 'alaih.

c. Wakaf uang yang disusun dalam skim saham sebagai penyertaan dalam wakaf

Bentuk wakaf uang yang disusun dalam skim saham wakaf, sering diistilahkan sebagai wakaf saham dalam praktik di Malaysia. Pada skim ini wakif melalui wakaf uang dengan cara membeli unit-unit saham tersebut sesuai untuk tujuan wakaf seperti pembangunan rumah ibadah, pendidikan, pelayanan kesehatan, dan sebagainya untuk tujuan kepentingan dan kebajikan umat islam. Saham yang mereka maksud disini lebih merupakan pengertian keikutsertaan merka dalam pembangunan suatu proyek wakaf untuk tujuan sosial bukan untuk diinvestasikan sebagai modal.

d. Wakaf saham milik

Pada mekanisme wakaf saham ini, wakif memang sebelumnya merupakan pemegang saham suatu perusahaan, kemudian mewakafkan saham yang dimilikinya tersebut. 
3. Implementasi Wakaf Saham Pada Emiten yang Keluar dari Daftar Efek Syariah (DES)

Terkait dengan metodologi hukum Islam, wakaf saham merupakan salah satu konsep fikih jtihad yang lahir dari pemahaman ulama terhadap nash-nash yang menjelaskan tentang pembelanjaan harta. Mengenai hal-hal yang tidak ada nashnya dalam al-Qur'an dan Hadits, sejauh dalam bidang muamalah (hubungan horizontal), pintu ijtihad terbuka lebar untuk dilakukan, termasuk persoalan wakaf saham. Karena tidak ada nash al-Qur'an dan sunah Rasulullah yang secara tegas melarang wakaf saham maka atas dasar mashlahah mursalah, wakaf saham dibolehkan, karena mendatangkan manfaat yang sangat besar bagi kemaslahatan umat, atau dalam istilah ekonomi dapat meningkatkan investasi sosial dengan mentransformasikan tabungan masyarakat menjadi modal umat. (Hendra Kholid, Wakaf Uang Perspektif Hukum dan Ekonomi Islam, http://bwi.or.id/index.php/ar/publikasi/ artikel/815-wakaf-uang-perspektif-hukum-danekonomi-islam.html)

Keuntungan atau dividen yang dihasilkan dari saham yang diwakafkan dalam sebuah perusahaan, maka keuntungan tersebut akan didistribusikan baik disalurkan langsung untuk kepentingan masyarakat atau sebagainya untuk diinvestasikan kembali untuk menigkatkan manfaatnya. (Budi Santoso:2011) Sementara itu ika investasi saham tersebut mengalami keruian atau tidak memperoleh dividen, maka tidak ada hasil yang dapat didistribusikan kepada penerima wakaf. Dengan demikian nazhir harus memiliki kompetensi dalam manajemen bisnis, melakukan pemilihan bidang investasi yang tidak mengandung resiko terlalu tinggi, serta upaya-upaya preventif lainnya dengan melakukan jaminan asuransi saham.

Tabung Wakaf Indonesia saat ini telah diberi amanah oleh empat wakif yang telah mewakafkan saham-sahamnya. Semua wakaf saham tersebut bersifat permanen/tetap. Model wakaf saham yang bisa dilakukan ada tiga hal, yaitu :

a) Wakaf saham oleh wakif kepada nazhir;

b) Wakaf uang kemudian nazhir akan membelikan saham sebgai program investasinya;

c) Wakaf dividen saham dimana saham masih atas nama wakif dan devidennya saja yang diwakafkan.

Pengelolaan investasi saham tentu harus sesuai syariah. Semua wakaf saham harus dalam saham yang terdaftar di Daftar Efek Syariah (DES) juga termasuk di JII (Jakarta Islamic Index). Adapun analisa yang dipakai cukup mengunakan analisa fundamental saja dengan mengabaikan analisa technical karena wakaf saham tidak diperbolehkan untuk diperdagangkan (sesuai kaidah syariah). (http://noviatiendangmustaqimah.blogspot. co.id/2011/11/introducing-wakaf-saham.html)

Saham-saham yang tidak terdaftar ataupun dikeluarkan dari Daftar Efek Syariah (DES) namun telah mewakafkan sahamnya di Tabung Wakaf Indonesia yaitu:

1) PT. Capitalinc Finansial

2) PT. Panin Life Finansial

3) PT Bentoel International

4) Jakarta Internasional Hotel

5) BII Tbk

6) Sahid Jaya Hotel

7) Bank Arthagraha International.

Pada saat ini saham yang sudah on-going process adalah PT Panin Life Finansial berupa konversi kepengurusan dari wakaf ke atas nama Dompet Dhuafa. Ada juga saham syariah tidak dijual karena sudah sesuai syariah dan cukup memberikan keuntungan berupa deviden yang mengalir terus. Wakaf saham dimaksud adalah saham syariah dari Hotel Sofyan Jakarta. (http:// tabungwakaf.com/wakaf-saham-di-twi-bisa/)

Saat ini portofolio surat berharga yang dimiliki Tabung Wakaf Indonesia adalah berupa wakaf saham dari beberapa donatur. Pengelolaan wakaf saham difokuskan pada komposisi portofolio yang 
dapat menghasilkan dividen yang optimal, sahamsaham dengan fundamental perusahaan yang baik serta dalam lingkup syariah. Sekuritas pencatat portofolio saham TWI adalah BNI Securuties. Per 31 Oktober 2011, nilai pasar atas portofolio saham yang dimiliki adalah sebesar Rp. 25,6 juta rupiah dimana 5 komposisi saham terbesar adalah:

1) PT Kalbe Farma, Tbk (40,7\%)

2) PT Astra International, Tbk (21,3\%)

3) PT Holcim Tbk (7,1\%)

4) PT Summarecon Agung, Tbk (3,6\%)

5) PT Jakarta International Hotel \& Development, Tbk (3,2\%)

Wakaf saham di TWI mulai tahun 2002. Sebelu dibentuknya TWI wakaf saham ini masih deserahkan oleh wakif kepada yayasan Dompet Dhuafa. Pada awalnya, TWI belum terlalu serius mengelola wakaf saham tersebut sebagai aset wakaf, baru kemudian pada tahun 2010 mulsi dilakukan pendataan secara serius dengan pencatatan saham sebagai aset wakaf, antara lain dilakukannya proses balik nama. Hal ini dilakukaan karena pada awalnya, wakaf saham di TWI masih tercatat wakif sebagai pemegang waham, sementara yang diwakafkannya hanya devidennya saja.

\section{E. Kesimpulan}

Berdasarkan hasil penelitian dan pembahasan, maka dapat disimpulkan:

1. Mekanisme wakaf melalui instrumen saham, yaitu: pertama, wakaf uang yang diinvestasikan melalui saham, wakaf uang ini dapat dilakukan dengan menginvestasikan dananya melalui pembelian saham-saham perusahaan baik melalui pasar modal maupun tidak. Pada praktik wakaf ini, yang menjadi objek wakaf adalah uang, hanya bentuk investasinya dikelola melalui saham. Kedua, Wakaf Saham melalui uang, pada mekanisme ini wakaf dapat mewakilkan pada pihak nazhir atau pihak lainnya dengan menitipkan sejumlah uang yang kemudian dibelikan atau ditukar dengan saham, kemudian saham tersebut diwakafkan. Ketiga, wakaf uang yang disusun dalam skim saham sebagai penyertaan dalam wakaf, bentuk wakaf uang yang disusun dalam skim saham wakaf, wakif melalui wakaf uang dengan cara membeli unit-unit saham tersebut sesuai untuk tujuan wakaf seperti pembangunan rumah ibadah, pendidikan, pelayanan kesehatan, dan sebagainya untuk tujuan kepentingan dan kebajikan umat islam. Keempat, wakaf saham milik, Pada mekanisme wakaf saham ini, wakif memang sebelumnya merupakan pemegang saham suatu perusahaan, kemudian mewakafkan saham yang dimilikinya tersebut.

2. Karakteristik emiten yang sesuai dengan daftar efek syariah, berdasarkan fatwa Dewan Syariah Nasional (DSN) No. 20. emiten yang kegiatan usahanya tidak bertentangan dengan syariah seperti usaha perjudian, lembaga keuangan konvensional (ribawi), asuransi konvensional, usaha yang memproduksi, mendistribusi serta memperdagangkan makanan dan minuman yang tergolong haram dan usaha yang memproduksi, mendistribusi dan atau menyediakan barang-barang ataupun jasa yang merusak moral dan bersifat mudarat. Selain kriteria di atas, kriteria emiten dilihat dari rasio keuangannya yaitu: pertama, rasio total utang ribawi (berbasis bunga) dibandingkan dengan total asset: tidak lebih dari 45\%. Kedua, kontribusi pendapatan non-halal dibandingkan dengan pendapatan: tidak lebih dari 10\%.

3. Analisis hukum ekonomi syariah terhadap wakaf saham bagi emiten yang keluar dari daftar efek syariah (DES), tidak ada nash alQur'an dan sunah Rasulullah yang secara tegas melarang wakaf saham maka atas dasar mashlahah mursalah, wakaf saham dibolehkan, karena mendatangkan manfaat yang sangat besar bagi kemaslahatan umat, atau dalam istilah ekonomi dapat meningkatkan investasi sosial dengan mentransformasikan tabungan masyarakat menjadi modal umat. Namun, Jika wakif (emiten) masih dalam saham 
konvensional (tidak terdaftar di Daftar Efek Syariah) maka status wakaf tersebut tidak sah karena bertentangan dengan prinsip syariah yang tercantum dalam fatwa DSN maupun P-OJK, Tabung Wakaf Indonesia harus mengkonversinya terlebih dahulu kedalam saham-saham syariah. Proses konversi saham ini yang harus ditegaskan agar status wakaf saham menjadi transparan dan accountable, sehingga bisa di pertanggungjawabkan secara administrasi dan mengurangi resiko human error.

\section{Daftar Pustaka}

Abdul Ghofur Anshori, Hukum dan Praktik Perwakafan Di Indonesia. Yogyakarta, Pilar Media, 2006.

Adrian Sutedi, Pasar Modal Syariah, Jakarta, Sinar grafika, 2011.

Amiruddin, Pengantar Metode Penelitian Hukum. Jakarta, PT Raja Grafindo Persada, 2006.

Andi Prastowo, Metode Penelitian Kualitatif dalam Perspektif Rancangan Penelitian, Yogyakarta, Gadjah Mada University Press, 2012.

Az-Zuhaili, Wahbah. Terjemah Figh Islam Wa Adilatuhu jilid IV. Jakarta, Gema Insani, 2007.

Cholid Narbuko dan Abu Achmadi, Metodologi Penelitian, Jakarta, PT. Bumi Aksara, 2003.

Khaerul Umam, Pasar Modal Syariah dan Praktik Pasar Modal Syaria, Pustaka Setia. Bandung, 2013.

Kansil, C.S.T., Drs, SH, Pengantar Ilmu Hukum Jilid I, Balai Pustaka, Jakarta 2008.

Lexy J. Moleong, Metodelogi Penelitian Kualitatif, Ed. Rev, Jakarta, Remaja Rosdakarya, 2010.

Marzuki, Metodologi Riset, Yogyakarta, PT. Hanindita Offset, 1983.

Santoso, Budi. Wakaf untuk Perusahaan Model CSR Islam untuk Pembangunan Berkelanjutan, Malang, UB Press, 2011. Suharsimi Arikunto, Prosedur Pendekatan Praktik, Edisi Revisi, Cet. 14, Jakarta. Rineka Cipta, 2010.
Sudarto, Metodologi Penelitian Filsafat, Jakarta. Raja Grafindo Persada, 2002.

Soerjono Soekanto, Pengantar Penelitian Hukum, Jakarta: Universitas Indonesia, 1986.

Waluyo, Bambang. Penelitian Hukum Dalam Praktek, Jakarta, Sinar Grafika, 2002.

http://tabungwakaf.com/profil-tabung-wakafindonesia/ artikel diakses pada tanggal 20 Mei 2018

Fitra Mizan, Efektifitas Tabung Wakaf Indonesia (TWI) dalam Perhimpunan dan Pendayagunaan Wakaf. Jakarta: UIN Syarif Hidayatullah, 2007.

http://bwi.or.id/index.php/ar/publikasi/ artikel/815-wakaf-uang-perspektif-hukumdan-ekonomi-islam.html, diakses pada tanggal 20 Mei 2018

http:// noviatiendangmustaqimah.blogspot. co.id/2011/11/introducing-wakaf-saham. html diakses pada 21 Mei 2018.

http://tabungwakaf.com/wakaf-saham-di-twibisa/ diakses pada tanggal 23 Juni 2018 pukul 13.45

http://tabungwakaf.com/wakaf-saham-di-twibisa/ diakses pada tanggal 23 Juni 2018 pukul 13.45

Surat Berharga, http://www.tabungwakaf.com/ index.php/portofolio/surat-berharga.html, diakses pada 21 Mei 2018.

http://www.ojk.go.id diakses pada tanggal 14 Desember 2018, pukul 14.30

http://www.ekonomisyariah.org/5620/ mengenal-wakaf-saham/ Diakses Pada 03 Desember 2018

http://siwak.kemenag.go.id/ (diakses pada tanggal 26 desember 2018, pukul 12.42

http://akucintakeuangansyariah.com diakses pada tanggal 23 Desember 2018, pukul 14.30

http://tabungwakaf.com/wakaf-saham-di-twibisa/ diakses pada tanggal 23 Juni 2018 pukul 13.45

Fatwa DSN MUI No: 40/DSN-MUI/X/2003 tentang Pasar Modal Syariah

UU NO. 41 Tahun 2004 tentang Wakaf. 